\title{
Re/Engaging Street to Address Multiplicity in Composition Classrooms
}

\section{Vivette Milson-Whyte-The University of the West Indies}

T

$\mathrm{n}$ this symposium piece, I consider how Brian Street's ideas have been picked up in the teaching of postsecondary writing in the Caribbean and suggest some aspects of his work that might still prove useful in the teaching of academic writing there and elsewhere in the $21^{\text {st }}$ century. Teaching and researching in academic writing in my natal space of the Caribbean but having studied rhetoric and composition and taught firstyear composition in the US, I will be shuttling between the two spaces. I will begin with some context for my work and then examine past and potential engagements with Street's ideas.

\section{Street Matters}

Street's ideas about what he terms and critiques as "autonomous" literacy and its "ideological" counterpart (Literacy) are enacted in the UK instantiation of the teaching of academic writing called "Academic Literacies." Proponents of Academic Literacies (as opposed to Study Skills and Academic Socialization models, which are both informed by a view of literacy as autonomous and ideologicallyneutral) promote literacy as social action (Street, "Academic Literacies"), highlight differences in knowledge creation and in reading and writing practices and processes in varying discourse communities, and call for faculty members to engage in "critical reflexivity" (Street, "Academic Literacies") and make discourse practices visible to students. Given continuous expansions in higher education in the Caribbean and elsewhere-more students and more variation in literacies and in traditionally defined writing proficiency-Street's notions of critical reflexivity and an ideological (vs. autonomous) model of literacy as social practice will remain relevant to developing theories/ principles and practices for academic writing education. At the same time, academic writing instructors, intent on the academic writing development of users of minoritized languages (and of other students), can also call on Street to help them address what may be perceived as perplexing practices of these same students.

\section{Research Matters}

Theresa Lillis and Mary Scott have accurately noted what could easily be my research experience. They have written: "In exploring what is involved and at stake in student writing, teacher-researchers have drawn on the available and influential paradigms in their specific geo-historical contexts ... In the UK, until recently, student academic writing tended to remain invisible as an object both of pedagogy and research. The most visible frame of reference has been English for Academic Purposes (EAP) ...." (Lillis and Scott 9-10). I have been working to make student academic writing and its 
instruction and study visible in the Caribbean context, and operating based on research practices aligned with literary (textual) study and applied linguistics. To produce the first full length book about academic writing education and attitudes to it in Jamaica, I did qualitative research involving analyses of archival materials and data gathered from questionnaires and interviews with past and current writing specialists (Milson-Whyte, Academic). Using observations, experiential data, and other textual analyses, I glean much about the workings of language in society and in formal educational institutions (Milson-Whyte, "Caribbean," "Pedagogical"; Milson-Whyte, Oenbring, and Jaquette.). I include student perspectives in my work by doing phenomenological studies that provide data about students' perceptions of and work with postsecondary writing (Milson-Whyte "Economies," "Working"; Jones and Milson-Whyte), and I frequently make comparisons with the well-established tradition of teaching composition in the United States and with the more recent development of teaching academic writing/literacies in the United Kingdom (UK) because of my experiences in the US and on account of ideas I glean via disciplinary conferences and publications.

\section{Curriculum Matters: \\ Past and Current Uses of Street's Oeuvre in Course/Program Content}

With regard to curriculum matters, based on my investigations, Street's work, especially regarding literacy as social practice, was picked up by scholar-researchers in the Caribbean in the $20^{\text {th }}$ century to the point that his ideas were "flattened"-became axiomatic. One survey respondent, a retired professor of literacy studies/language education, expressed it this way: "I think the view of literacy as social practice is almost axiomatic now. I first encountered Street in the early 80 s so anything I've written takes that orientation for granted" (Bryan). Also taken for granted for a long time in the Caribbean is the view that there are different kinds of literacies, one of which is academic literacy that is supposed to be taught in universities as different from what is required in secondary schools. Charles Bazerman's observation is, therefore, applicable to the Caribbean: “The near universality of the first-year ... writing requirement contains an implicit recognition that in higher education new levels of writing and expression are demanded" (2). However, the singular understanding of literacy manifested in the teaching of a single academic writing course for nearly half a century on the campuses of the premier institution of higher education in the Anglophone Caribbean and for many years in other institutions, the only difference being that a course might have changed name over the years-sometimes in response to specific institutional changes and sometimes on account of misunderstanding of a course based on the inclusion of terms such as English in the name in specific institutions (see Jones McKenzie and Campbell-Dawes; Milson-Whyte, Academic). Additionally, given the influence of the work of Street and others, emphasizing social practices around literacy, a process approach to writing is common in these courses. However, this has not been to the extent that focus on "product"/text has been minimized; in fact, the opposite is true to the extent that an investigator is likely to find "superficial elements of process writing grafted onto a product-driven system" (Milson-Whyte, Academic 152). There is, then, no great worry that in the turn to social processes, there was abandonment of "text" as Suresh Canagarajah has noted was generally the case 
elsewhere ("Weaving" 11-12; see also Lillis and Scott 21).

More recently, there has been expanding uptake of Street's ideas via Academic Literacies in the Caribbean in graduate and undergraduate academic writing curriculum, in proposals for program amendments (including changing names of programs), and in calls for advocacy and professionalization of academic writing instructors (see Jones McKenzie and Campbell-Dawes; Rose). These more recent inclusions of his work in Caribbean spaces suggest moves that could be beneficial to students and facilitators of writing courses in areas in which students' vernaculars are minoritized; however, Street would probably judge these inclusions as being more "normative" than "transformative." In the Caribbean, there is still a focus on academic literacy as singular and autonomous-as an entity needed for success in university studies and beyond. The study skills or academic socialization models present heavily even in places where courses are aligned with faculties/colleges. At the undergraduate level, since 2013, the premier university adopted facultyspecific (that is, college-specific) academic writing courses reflecting emphasis on social practices and acknowledgement of differences in knowledge and writing production. This change signalled a departure from one generic course (English for Academic Purposes) for all students on the institution's campuses across the Caribbean region. However, in and across institutions, courses still seem to be about just a little more than the study skills model: that is, academic socialization. I have drawn on an Academic Literacies framework to demonstrate that although instances in which courses are aligned with faculties suggest a recognition of disparate discourse practices, one academic writing course per faculty/college seems to ignore the fact that colleges are not homogenous (Milson-Whyte, Academic). Moreover, course outlines do not suggest engagement with questioning power structures, for example, or for considering students' "funds of knowledge” (Vélez-Ibáñez and Greenberg) — their linguistic currencies that are not valued in largely English-Only programs. In practice, students may be told that they should ask their professors about elements like meanings of instruction terms that differ depending not just on discipline but sometimes also on facilitator. Still, the academic writing courses do not seem to fully engage with matters of identity and epistemology-still seeming to privilege general skill and/or general socialization into a specific vein of academic discourse-and academic writing education occurs, as in other jurisdictions, with little to no explicit input from faculty in students' core courses.

\section{Language Matters: Street's Pull on Changing Cohorts and Linguistic Influences on Pedagogy}

Beyond inclusion in curriculum matters, Street's ideas have influenced—even if obliquely—some pedagogical responses to changing cohorts of students and by extension linguistic configurations in classrooms. In other words, when/where language matters, there always were "cracks" in the system, as Street noted in other places and expressed in a joint interview with Harvey Graff (de Oliveira Galvão, Soares de Gouvêa, and Rabelo Gomes 63, 64). In the Caribbean, simultaneous with academic writing education in standard(ized) languages, there have been calls to legitimize the Creole languages spoken by the majority in each country and that university students presented increasingly 
after the 1960s. The kind of advocacy work in the US leading to the 1974 Conference on College Composition and Communication's position statement "Students' Right to Their Own Language" is, therefore, ongoing in the Caribbean (most recently in a 2019 global call for signatories to a petition to make Jamaican Creole an official language in Jamaica). Beyond the Caribbean, as "cracks" have widened globally, we have seen calls to make pedagogy respond to increasing "diversity" in student populations-from Writing Across the Curriculum/Writing in the Disciplines programs (Russell) and teaching of Academic Literacies (Lea and Street; Jones, Turner, and Street; Lillis; Lea) to explicit calls for various linguistic engagements such as code-meshing-blending languages and styles (Canagarajah, "Place," "Multilingual"; Young); cross-languaging-working with, in and across more than one language (Horner, Lu, and Matsuda, Cross-Language); and translingualism-which values difference in language and encourages negotiating in the available languages in a student's linguistic repertoire to arrive at meaning in interactions instead of relying on fixed forms or rules (Horner, Lu, Royster, and Trimbur, "Language Difference"). The support and critiques of these linguistic and pedagogical engagements have been many; most recently Bruce Horner and Sara Alvarez have tried to distance translinguality from the others and the more recently used term translanguaging. In and outside of the Caribbean, in institutions where the strict focus in teaching is on helping students to develop some singular academic literacy, it is usually expected that multilingual students will engage in code-switching-using standard(ized) language in/for their academic writing courses and other forms for other purposes. Outside of the Caribbean, where programs/institutions allow for radical engagements, instructors allow students to engage in blending styles and languages; however, some approaches, as in Peter Elbow's suggestion to have students do drafting in their vernaculars and then edit these out in final drafts, are critiqued as half-measures (see Robinson, for example).

As some composition instructors in the US and elsewhere are aware, students of Caribbean heritage do/use language in interesting ways because of their experiences with two or more varieties of language. Instructors do not always understand these students' ways of languaging, and the students' perceptions of and declarations about their languaging tend to be different from instructors' perceptions-as Shondel Nero has documented regarding Caribbean students in the US who profess to be native English speakers/speakers of English, contradicting what instructors detect in their speech and writing. The similarities and differences in the varieties of language these students use suggest that they could benefit from proposals for code-meshing or translingualism in their development of academic literacies. However, as outlined in various publications, there could be challenges for instructors who try to implement these proposals among Caribbean students. For starters, proposals regarding "inclusion" of students' languages in classrooms seem to assume (equal) valuing of the languages in a student's repertoire, orthography developed for the languages in a student's repertoire, and literacy in more than one of the languages in the student's repertoire (see Milson-Whyte, "Working"). These assumptions can be problematic for Caribbean students or students of Caribbean heritage, given their linguistic range.

For context, students from the Francophone (French-speaking) Caribbean have experience with (standardized) French language and a French Creole, and generally the language of instruction is French. The exception is Haiti, because Haitian Creole is also an official language. Students from 
the Hispanophone (Spanish-speaking) areas have experience with (standardized) Spanish(es), indigenous languages, local Spanish-lexified vernaculars (and Englishes). The language of instruction is generally Standardized Spanish. In the Dutch-Speaking Caribbean, students have experience with (standardized) Dutch, Papiamentu/o (Portuguese-based Creole), and the language of instruction is Dutch (generally) but Papiamentu in Curaçao. In the Anglophone (English-speaking) Caribbean, (standardized) Englishes (referred to as Standard English or Caribbean Standard English or by island name such as Jamaican Standard English) and English-lexified Creoles obtain; French Creoles are also in place in English-speaking St. Lucia and Dominica. However, the language of instruction is English (see Milson-Whyte, "Caribbean").

Admittedly, most Caribbean students in US composition classrooms are likely to be from the Anglophone Caribbean, and especially Jamaica, but multiplicity remains. The variety of practices amongst Jamaican students led me to define them as Creole-influenced:

Some Jamaicans are English-only speakers who understand Creole; some are Englishdominant bilinguals; some are Creole-dominant bilinguals; some may be equally bilingual in Creole and English; some are Creole-only speakers who may or may not understand English; some slide between the shifting poles in ways yet to be named; some do not acknowledge their linguistic profiles and behaviours, but all encounter Jamaican Creole. Since all Jamaicans are influenced in one way or another by the Creole, but are not all Creole-speaking, I refer to Jamaican students as Creole-influenced students. (Milson-Whyte, Academic 6)

Needless to say, this is a challenging situation. Recall Braj Kachru and the challenge of placing Jamaica and other Caribbean islands in his concentric circles as he couldn't determine if citizens could be considered native or non-native speakers of English (362). In the Caribbean context, Creoles are stigmatized and this stigma is internalized by some Creole-speakers; English-as-mother-tongue tradition is prevalent and there are high failure rates in a system steeped in high-stakes testing; and "naturalized double consciousness" is evident in those who naturally/automatically separate their languages and function (seemingly) without underlying tensions-those considered artful codeswitchers who find strange written Creole, especially when it is combined with English (see MilsonWhyte, "Pedagogical”).

Reflecting on these "cracks" and attempts to address linguistic diversity in pedagogically sound ways would mean, in Street-like approaches, to consider the multiple linguistic groups represented in any one classroom and the multiple attitudes of Caribbean students toward Creoles in classrooms. Among students who could be invited to engage their various languages in an assignment would be those who experience difficulty writing in English (and could therefore not make up even "eyedialect" written Creole words), those uncomfortable with the suggestion to use Creole in class, and those who have a neutral response to invitations to engage with their full linguistic repertoire/s and would attack the assignment as one given in English only (see Milson-Whyte, "Working"). Among the explanations for these varying attitudes are the facts that for a long time there was no developed orthographic system for Creoles (exceptions being Haitian Creole and Papiamentu); generally, Caribbean students still do not develop literacy in their Creoles; students are not taught 
contrasts between the standardized language/s and the Creole languages; and weaker writers tend to confuse standardized English and their English-lexified Creole. To my mind, even though proponents of code-meshing and translingualism do not have a stated or implied goal of students' being able to separate out their languages as they work on developing academic literacies, blending of elements from different languages (code-meshing) or negotiating meanings in or across languages (translingualism) does suggest an understanding/knowledge of the different elements of each language - and this is a challenge for weaker writers who are like a study participant I've described elsewhere (Milson-Whyte, "Economies"). He is "challenged, like other male students, to transform his power to talk into proficiency in writing in the formal, structured classroom setting because he cannot produce the appropriate currency. For him, writing is 'swimming through some rough waters" (Milson-Whyte, "Economies" 572). He acknowledged the following:

For me, most times to speak in English I will practice patois so much and block English so much that when I'm required to use it in strict formalities, it poses a problem. And I think that probably it is one of the main reason why I don't write well because I am thinking these thoughts ... You can't say them in patois and write them in English. So that comes as a problem because to substitute the words is difficult to keep the same meaning. I can't speak very well so each time I try to translate my thoughts to written formality it's a burden. This formality that is required makes all my ideas turn into something else . . it made me feel like a mad man because it [sic] can’t write what I think. (Milson-Whyte, "Economies" 572-73)

Perhaps, then, it is not surprising that in the Caribbean, calling on some social practices can be rare in the composition classroom. One still has to make a case for including Creole in academic writing education (see Carmeneta Jones, “Teaching Literacy Skills"), and expatriates-not locals—seem most invested in calling on the oral penchant of Caribbean students in teaching English composition in Caribbean classrooms (see Dyer-Spiegel; Oenbring).

\section{Future Matters: More Potential In Street's Ideas}

To date, in the Caribbean and elsewhere, we are still needing to treat with understandings of academic literacy as singular and with colonial attitudes that prevail regarding language matters (work in English and English only, or work involving other languages to be edited out before final drafts in standardized language are submitted, as per Peter Elbow, or work across languages in ways that-ironically_seem strange to people for whom work across languages is a quotidian activity). We still are needing to consider adjusting arrangements for teaching and attitudes to Caribbean and other minoritized students' languaging labors to yield more just, productive, and positively transforming teaching-learning postsecondary composition spaces. And added to the mix are technological developments and global challenges that are rendering increasingly complex students' usual "funds of knowledge" (Vélez-Ibáñez and Greenberg). 
Three of Street's recommendations are particularly apt in this regard:

In order to build upon the richness and complexity of learners' prior knowledge, we need to treat 'home background' not as a deficit but as affecting deep levels of identity and epistemology, and thereby the stance that learners take with respect to the 'new' literacy practices of the educational setting. ("At Last" 420)

... there are of course context specific features to writing in the Academy, as in other contexts, even whilst these can also be defined as 'social.' But frequently these features may "remain 'hidden.' ("Symposium Comments" 39)"

Very often, there are hidden literacies that people aren't aware of, and very often you can build on the literacies people bring with them and then extend them according to the context. (qtd. in de Oliveira Galvão, Soares de Gouvêa, and Rabelo Gomes 57)

All three recommendations indicate that explicit teaching is necessary for students' development. To some of us, this is a truism, but it is also true that far fewer content specialists (beyond writing studies) than academic writing educators would like are explicitly involved in contributing to students' academic writing development. This shortcoming is hinted at in the second recommendation that includes an important acknowledgement from Street: While he insists on the social nature of literacy and writing, he is careful to acknowledge "context specific features to writing"-but these have to be made visible to learners. Similarly, learners have experiences with literacy that put them in good stead in other contexts like an academic one, but some knowledgeable other has to help to bring such "hidden literacies" to conscious awareness from whence they can be expanded. The first recommendation suggests that these modes of extracting and expanding prior literacy knowledge are critical because of their emotional and intellectual weight. Rather than a hindrance to development, the known-with its connections to sense of self, knowledge-making, and outlook-influences comprehension and interpretation of new literacy contexts and development in them. All of these, then, seem applicable to not only Caribbean students or students who use minoritized languages but also students who might consider themselves monolingual, monocodal or monomodal.

Ultimately, engaging with Street's recommendations might help us to address curricular changes, occasioned in part by students' linguistic diversity and compounded by the challenges and opportunities presented by new technologies or situations, such as a persistent pandemic, to which educational responses could disenfranchise the already marginalised and magnify inequities (see Brabazon). Undoubtedly and increasingly, students-some probably deemed short on academic (English) language skills-will present not only with multiple other linguistic and cultural literacies but also with technological savviness or limitations that will demand that educators pluralize literacy curricula and academic writing pedagogy unendingly. In what might appear future matters, both present and future will matter as they are made to collide, silence or be silenced, or coexist cooperatively. 


\section{WORKS CITED}

Bazerman, Charles. "Introduction." Handbook of Research on Writing: History, Society, School, Individual, Text, edited by Charles Bazerman, Lawrence Erlbaum Associates, 2008, pp. 1-4.

Brabazon, Honor. “The Academy's Neoliberal Response to COVID-19: Why Faculty Should Be Wary and How We Can Push Back." Academic Matters: OCUFA's Journal of Higher Education, May 2020, academicmatters.ca/neoliberal-response-to-covid-19/. Accessed 5 June 2020.

Bryan, Beverley. "Re: Request re Brian V. Street.” Received by Vivette Milson-Whyte, 11 Mar. 2019. Canagarajah, A. Suresh. "Multilingual Strategies of Negotiating English: From Conversation to Writing." JAC: A Journal of Composition Theory, vol. 29, no.1/2, 2009, pp. 17-48.

---. "The Place of World Englishes in Composition: Pluralization Continued." College Composition and Communication, vol. 57, no. 4, 2006, pp. 586-619.

---. "Weaving the Text: Changing Literacy Practices and Orientations." College English, vol. 82, no.1, 2019, pp. 7-28.

CCCC (Conference on College Composition and Communication). "Students' Right to Their Own Language." College Composition and Communication, vol. 25, no. 3, 1974, pp. 1-32.

de Oliveira Galvão, Ana Maria, Maria Cristina Soares de Gouvêa, and Ana Maria Rabelo Gomes. "An Interview with Harvey J Graff \& Brian Street." Literacy in Composition Studies, vol. 5, no.1, 2017, pp. 49-66, licsjournal.org/OJS/index.php/LiCS/article/view/138/206. Accessed 30 Nov. 2019.

Dyer Spiegel, Jacob. "Building around Nation Language: A Critical Reflection on Teaching Composition at the University of The Bahamas." Milson-Whyte, Oenbring, and Jaquette, pp. 76-103.

Elbow, Peter. "Inviting the Mother Tongue: Beyond 'Mistakes,' Bad English,' and 'Wrong Language." JAC: A Journal of Composition Theory, vol. 19, no. 3, 1999, pp. 359-88.

---. Vernacular Eloquence: What Speech Can Bring to Writing. Oxford UP, 2012.

Horner, Bruce, and Sara P. Alvarez. "Defining Translinguality." Literacy in Composition Studies, vol. 7, no. 2, 2019, pp. 1-30, licsjournal.org/OJS/index.php/LiCS/article/view/221. Accessed 27 Dec. 2019.

Horner, Bruce, Min-Zhan Lu, and Paul Kei Matsuda., editors. Cross-Language Relations in Composition. Southern Illinois UP, 2010.

Horner, Bruce, Min-Zhan Lu, Jacqueline Jones Royster, and John Trimbur. "Language Difference in Writing: Toward a Translingual Approach.” College English, vol. 73, no. 3, 2011, pp. 303-21.

Jones, Carys, Joan Turner, and Brian Street, editors. Students Writing in the University: Cultural and Epistemological Issues. John Benjamins, 1999.

Jones, Carmeneta. "Teaching Literacy Skills in the Jamaican Creole-Speaking Environment: A Reflection.” Milson-Whyte, Oenbring, and Jaquette, pp. 39-75.

Jones, Carmeneta, and Vivette Milson-Whyte. "Metaphors of Writing and Intersections with Jamaican Male Identity." International Advances in Writing Research: Cultures, Places, Measures, edited by Charles Bazerman, et al., The WAC Clearinghouse; Parlor P, 2012, pp. 267-84.

Jones McKenzie, Clover, and Tresecka Campbell-Dawes. “Academic Literacies: Literacy Facilitators' 
Framework for Self-empowerment in the Anglophone Caribbean Postsecondary Context." Milson-Whyte, Oenbring, and Jaquette, pp. 303-19.

Kachru, Braj B. “Teaching World Englishes.” The Other Tongue: English Across Cultures. $2^{\text {nd }}$ ed., edited by Braj B. Kachru, U of Illinois P, 1992, pp. 544-65.

Lea, Mary R. “Academic Literacies: A Pedagogy for Course Design.” Studies in Higher Education, vol. 29, no. 6, 2004, pp. 739-56, doi: 10.1080/0307507042000287230. Accessed 29 Nov. 2019.

Lea, Mary R., and Brian V. Street. "Student Writing in Higher Education: An Academic Literacies Approach." Studies in Higher Education, vol. 23, no. 2, 1998, pp. 157-72, doi: 10.1080/03075079812331380364. Accessed 20 Dec. 2019.

Lillis, Theresa. "Student Writing as 'Academic Literacies': Drawing on Bakhtin to Move from Critique to Design." Language and Education: An International Journal, vol. 17, no. 3, 2003, pp. 192-207, doi: 10.1080/09500780308666848. Accessed 20 Dec. 2019.

Lillis, Theresa, and Scott, Mary. "Defining Academic Literacies Research: Issues of Epistemology, Ideology and Strategy." Journal of Applied Linguistics, vol. 4, no. 1, 2007, pp. 5-32, doi: 10.1558/ japl.v4i1.5. Accessed 30 Nov. 2019.

Milson-Whyte, Vivette. Academic Writing Instruction for Creole-Influenced Students. Jamaica, The U of the West Indies P, 2015.

---. “Caribbean Creole-Speaking Cultures, Language, and Identity." The TESOL Encyclopedia of English Language Teaching, edited by John Liontas, vol. 6 (edited by Shondel Nero), John Wiley and Sons, Inc., 2018, pp. 3483-89, doi: 10.1002/9781118784235.eelt0304. Accessed 29 Nov. 2019.

---. "Economies, Identities, and Perceptions of Writing: Self-Portraits and Academic Writing Performance among Jamaican Students." JAC: A Journal of Composition Theory, vol. 32, no. 3/4, 2012, pp. 565-90.

---. "Pedagogical and Socio-Political Implications of Code-Meshing in Classrooms: Some Considerations for a Translingual Orientation to Writing." Literacy as Translingual Practice: Between Communities and Classrooms, edited by A. Suresh Canagarajah, Routledge, 2013, pp. 115-27.

---. "Working English through Code-Meshing: Implications for Denigrated Language Varieties and Their Users." Reworking English in Rhetoric and Composition: Global Interrogations, Local Interventions, edited by Bruce Horner and Karen Kopelson, Southern Illinois UP, 2014, pp. 10315.

Milson-Whyte, Vivette, Raymond Oenbring, and Brianne Jaquette, editors. Creole Composition: Academic Writing and Rhetoric in the Anglophone Caribbean. Parlor P, 2019.

Nero, Shondel J. “English is my Native Language ... or So I Believe." TESOL Quarterly, vol. 31, no. 3, 1997, pp. 585-93, doi:10.2307/3587842. Accessed 30 Nov. 2019.

---. "Language, Identity, and Education of Caribbean English Speakers." World Englishes, vol. 25, no. 3/4, 2006, pp. 501-11, doi: 10.1111/j.1467-971X.2006.00470.x. Accessed 30 Nov. 2019.

Oenbring, Raymond. "The Small Island Polis: Rhetorical Pedagogy in the Caribbean." MilsonWhyte, Oenbring, and Jaquette, pp. 271-84.

Robinson, Heather M. "Postcolonial Composition: Appropriation and Abrogation in the Composition 
Classroom." Milson-Whyte, Oenbring, and Jaquette, pp. 32-42.

Rose, Pamela. "A Case for Academic Literacies: Informed Needs Analysis." UWI Quality Education Forum, vol. 21, 2016, pp. 42-62.

Russell, David R. Writing in the Academic Disciplines: A Curricular History. $2^{\text {nd }}$ ed., Southern Illinois UP, 2002.

Street, Brian V. "Academic Literacies and the 'New Orders': Implications for Research and Practice in Student Writing in Higher Education." Learning and Teaching in the Social Sciences, vol. 1, no. 1, 2004, pp. 9-20, doi: 10.1386/ltss.1.1.9/0. Accessed 7 Nov. 2019.

---. "At Last: Recent Applications of New Literacy Studies in Educational Contexts." Research in the Teaching of English, vol. 39, no. 4, 2005, pp. 417-23, library.ncte.org/journals/rte/issues/v394/4482. Accessed 7 Nov. 2019.

---. Literacy in Theory and Practice. Cambridge UP, 1984.

---. "Symposium Comments." Literacy in Composition Studies, vol. 1, no. 1, 2013, pp. 38-41, licsjournal.org/OJS/index.php/LiCS/article/view/9. Accessed 20 Dec. 2019.

Vélez-Ibáñez, Carlos, and James Greenberg. "Formation and Transformation of Funds of Knowledge." Funds of Knowledge: Theorizing Practices in Households, Communities, and Classrooms, edited by Norma González, Luis C. Moll, and Cathy Amanti, Lawrence Erlbaum Associates, 2005, pp. 47-69. Originally published as "Formation and Transformation of Funds of Knowledge Among U.S.-Mexican Households" in Anthropology and Education Quarterly, vol. 23, 1992, pp. 313-35. Young, Vershawn Ashanti. "Nah, We Straight': An Argument Against Code Switching." JAC: A Journal of Composition Theory, vol. 29, no. 1/2, 2009, pp. 49-76. 